д-р Даниела Станојковска

ЈУ Завод за социјални дејности - Скопје

\title{
ЗНАЕЊА НА ПРОФЕСИОНАЛЦИТЕ ЗА ОБЕЗБЕДУВАЊЕ СОЦИЈАЛНИ УСЛУГИ ЗА СТАРИТЕ ЛИЦА
}

\section{АПСТРАКТ}

Демографското стареење, кое сѐ повеќе станува реалност и во Република Северна Македонија, носи предизвици за развивање соодветни социјални услуги, согласно потребите на старите лица, но и потреба од стекнување и продлабочување на знаењата на професионалците кои ги обезбедуваат овие услуги. Сето ова се наметнува како потреба со една цел и тоа задоволување на потребите на старите лица.

Стручното усовршување на професионалците во социјалната заштита во Република Северна Македонија е дел од еден сеопфатен процес, кој се труди да ги следи европските трендови за континуиран професионален развој. Но, фактот дека развојот на социјалните услуги за старите лица, во нашата земја, следи поразвиена динамика во последните години, а се очекува побрзо да се развива со реформираниот систем на социјална заштита од 2019 година, ја наметнува и потребата за проучување на знаењата со кои професионалците влегуваат во давањето на социјалните услуги, како и потребата за нивно проширување и продлабочување. Овој труд е насочен кон проучување на знаењата на професионалците кои даваат социјални услуги на старите лица, а резултатите од спроведеното квантитативно истражување со професионалците, укажуваат на потребата за нивно зајакнување во текот на професионалната едукација и процесот на континуиран професионален развој.

Клучни зборови: знаења, професионалци, социјални услуги, стари лица.

\section{ВОВЕД}

Пирсал и Ханкс (Пеарсалл анд Ханкс, 2003) во Оксфордскиот речник знаењето го дефинираат како: „Факти, информации и вештини стекнати преку искуство и образование, теоретски и практично разбирање на предметот“ (Ohford Dictionary 2010:967).

Тревитик, знаењето го конципира во една рамка која се состои од три области:

- „теоретски знаења или теории;

- фактички знаења (вклучувајќи и истражувања) и

- пракса, односно практични или лични знаења“.

(Trevithick, 2009:25) 
Сето ова упатува на фактот дека знаењата имаат теоретско значење и се состојат од научни сознанија кои се добро систематизирани и генерализирани, а се однесуваат на одредена научна област. Затоа за секој професионалец посебно важно е да поседува знаења, кои ќе му овозможат успешно да ги реализира работните задачи на своето работно место. Покрај тоа знаењата се и многу динамични, бидејќи се во постојано движење и се менуваат под влијание на развојот на науката, што ја наметнува потребата од постојано инвестирање во нив како најзначаен човеков капитал.

Социјалната интервенција со стари лица најчесто се поврзува со геронтологијата и бара посебни сознанија за процесот на стареење, кој е заснован на биологијата, психологијата и општествените науки. Секоја од овие перспективи му овозможува на социјалниот работник да го разбере процесот на стареење на лично ниво и обезбедува основа која е потребна за да се разберат проблемите, ризиците и потребите на старите лица.

Потребата за специфично геронтолошко или геријатриско знаење не била препознаена во социјалната работа сѐ до средината на 20 век. Пред педесеттите години на социјалната работа со старите лица не се обрнувало внимание воопшто, додека крајот на шеесеттите и почетокот на седумдесеттите години е период кога старите лица почнуваат да се препознаваат како целна група за социјална интервенција. Во овој период, во суштина многу професии почнуваат да ја препознаваат потребата од специјализирани знаења и обуки на лицата кои треба да им дадат стручна поддршка на старите лица.

Непрепознавањето на старите лица како целна група за социјална интервенција, довела долго време да постои слаба подготвеност на професионалците за задоволување на потребите на населението кое сѐ поинтензивно старее. Така, ако во почетокот знаењата и вештините за работа со стари лица, биле обезбедени за многу мал број на студенти за социјална работа, подоцна била утврдена потребата покрај основните знаења социјалните работници да имаат можност да се стекнат и со специјализирани знаења од оваа област. Така социјалните работници треба да поседуваат знаења за современите теоретски концепти и практики во рамките на социјалната работа со старите лица и да развијат вештини за нивна конкретна, практична работа. Тие исто така треба да стекнат знаења за работа со луѓe со деменција и луѓе на кои им е потребна долготрајна нега дома или во установи за социјална заштита на стари лица.

Според Дамрон - Родригез и Корли, Беркман и други (Damron-Rodriguez and Corley, 2002; Berkman et all., 2007), главните области на знаење кои им се потребни на социјалните работници за работа на подрачјето на социјална интервенција со стари лица се дефинирани на Конференцијата во белата куќa, посветена на стареењето, одржана во 1995 година: „Разбирање на биопси- 
хосоцијалните перспективи, семејниот систем, развојот на животните фази, застапување, политиките и програмите на државата кои влијаат на старите лица и интердисциплинарната тимска работа“" (Gilmore, 2013:18).

Според Дамрон - Родригез и Корли, Беркман, Рован, Бурес, Вилсон и други, (Damron-Rodriguez and Corley, 2002; Berkman et all., 2007; Rowan et al., 2010; Bures at al., 2002; Wilson, 2006): „Coцијалните работници треба да имаат знаења за биопсихосоцијалните фактори релевантни за старите лица, како да работат во интердисциплинарни тимови и за ресурси специфични за потребите на старите лица“" (Ibid 1: стр. 19).

Имајќи предвид дека староста и стареењето носат голема хетерогеност во секојдневниот живот на постарите луѓе и специфични проблеми поврзани со староста и стареењето, а и дека 2020 година остави посебен белег на соочувањето на старите лица со предизвиците за зачувување на сопственото здравје и квалитет на живот во услови на пандемија, овој труд е посветен на проучување на знаењата на професионалците за социјална и здравствена заштита за старите лица, како исклучително неопходни знаења за обезбедување на социјалните услуги за старите лица.

\section{1. ЗНАЕЊА ЗА \\ СОЦИЈАЛНАТА И ЗДРАВСТВЕНАТА ЗАШТИТА НА СТАРИТЕ ЛИЦА}

\section{Знаења за правата и услугите од} социјална заштита насочени кон старите лица. Познавањето на системот на социјална заштита, поточно правата и услугите наменети за старите лица се клучни пред сѐ за социјалните работници, но и за кои било други професионалци вклучени во социјална интервенција со стари лица. И најдобрата проценка на состојбата на старото лице и неговото семејство, на нивните потреби и потенцијали се бесполезни доколку професионалците не знаат кои се услугите и правата од социјална заштита со кои може да се олесни или надмине социјалниот ризик кај старите лица. Познавањето на правата и услугите од социјална заштита е во основата на професијата на социјалната работа. Но, покрај правата и услугите од социјална заштита, професионалците кои работат со стари лица мора да имаат и знаења за правата и услугите од здравствена заштита, бидејќи староста и стареењето се ризици кои се тесно поврзани со промени во биопсихосоцијалното функционирање на лицата кои стареат.

Знаењата за ресурсите и услугите за социјална и здравствена заштита во суштина се составен дел од знаењата за работа во локалната заедница, како метод на социјална интервенција. „Социјалниот работник е орга- 
низатор на локалното население. Тој ги открива проблемите, ги дијагностицира и заедно со локалното население ги решава“ (Доневска, 2006:67). Локалната заедница во животот на старите лица има посебно значење, бидејќи во неа најчесто ги задоволуваат најголемиот дел од нивните потреби, а и поради нивната ограничена мобилност и намалена економска моќ. Притоа активностите во локалната заедница насочени кон задоволување на потребите на старите лица од страна на социјалните служби најчесто се препознаваат како активности на социјална интервенција, а многу ретко како социјална интеграција. Според Доневска: „Се работи за навистина оптимално решение сепак за кое е потребно, во рамките на социјалната помош на ниво на заедницата, да се вклучат и голем број субјекти од сферите на здравство, вклучувајќи и рехабилитација, помош во водење на домаќинствата итн. “" (Ibid 1: стр. 111). Затоа тесно поврзани со знаењата за работа во локална заедница се и знаењата за мапирање на услугите и сервисите од социјална и здравствена заштита, како и условите за подобност за користење на услугите од социјална и здравствена заштита.

Мапирање услуги и сервиси од социјална и здравствена заштита. На старите лица потребно им е што е можно подолго време да останат независни во своите домови, па дури и кога ќе се сместат во институции имаат потреба што е можно повеќе да ја задржат својата независност. Според Ровен и
Бурес (Rowan et al., 2010; Bures et al., 2002): „Со цел да им дадат поддршка на старите лица, за што е можно подолга независност, социјалните работници мора да имаат знаења за програмите на локално, државно и федерално ниво, кои се достапни за да им помогнат на старите лица да ги достигнат овие цели, вклучувајќки финансиски, нутриционистички, здравствени ресурси и ресурси за одржување во домот“" (Gilmore, 2013).

Голем дел од старите лица животот го поминуваат во своите домови, односно и покрај ограничувањата и тешкотиите кои може да им се јават заедно со староста сепак остануваат да живеат во своите природни средини. На овие стари лица потребна им е поддршка од ресурсите во средината, а социјалните работници вклучени во социјална интервенција со стари лица мора да имаат познавање на ресурсите, односно на сите даватели на услуги во нивната средина и пошироко, кои би можеле да ги задоволат здравствените и социјалните потреби на корисниците. Само така професионалците ќе можат да ја остварат крајната цел, поврзување на старите лица со најсоодветните услуги за нив, во моментот. Според Ровен (Rowan et al., 2010): „Социјалните работници мора да имаат подлабоки знаења за планирање и соодветно поврзување согласно подобноста со провајдерите (организациите кои даваат услуги за стари лица во заедницата) и ресурсите кои ги поддржуваат старите лица во заедницата“" (Gilmore, 2013:9). Притоа 
за професионалците не е важно само да имаат знаења од оваа област, туку и способност тоа да им го доближат и објаснат на старите лица, на начин кој ќе биде разбирлив за нив.

Во суштина ова се знаења кои се однесуваат на процесот на мапирање на ресурсите во локалната заедницата, но и на државно ниво, а кои можат да помогнат во задоволување на потребите на корисниците со кои тие работат. Според Доневска: „Мапирањето може да се врши на сите елементи во заедницата, или на некои нејзини избрани фрагменти“ (Доневска, 2006:141). Мапирањето опфаќа ресурси за сите видови на услуги неопходни за задоволување на секојдневните потреби на старите лица почнувајќи од транспорт, подготовка на оброци, здрава и правилна исхрана, финансии и управување со истите, достапност и набавка на лекови, здравствени установи и услуги, установи за социјална заштита и социјални услуги во заедницата, услуги за живеење со поддршка.

Во претставувањето на услугите пред корисниците, професионалците треба да имаат и соодвено знаење за приспособување на корисниците и семејствата кон болеста или состојбата на старите лица, при што посебно тешка задача која ја имаат е претставувањето на сервисите за долготрајна нега и грижа и хосписите. Социјалните работници во светот посебно ја истакнуваат потребата за зборување за хосписите уште многу рано, во раните фази на болеста, бидејќи многу индивидуи го завршува- ат својот живот без да ги почувствуваат бенефитите што тие им ги нудат, токму поради фактот што корисниците многу доцна се сместуваат таму. Во суштина никој не зборува со корисниците и со нивните семејства за смртта и умирањето, а професионалците вклучени во социјална интервенција со стари лица се единствените кои имаат храброст да го направат тоа.

Знаења за условите за подобност за користење на услугите од социјална и здравствена заштита. Професионалците покрај тоа што мора да ги познаваат и да ги имаат мапирано провајдерите на социјални и здравствени услуги во средината, тие мора да знаат и кои се условите за користење на истите, односно под кои услови старото лице може да се упати на користење на одредени услуги, кај одредени провајдери. Во овие случаи важно е и да се знае и точно видот, обемот и должината на траење на услугата, за да се направи правилно поврзување на потребите на корисниците и давателите на услугите.

Знаења за заштита од семејно насилство и злоупотреба. Професионалците кога ќе ги препознаат и идентификуваат случаите на злоупотреба и семејно насилство врз старите лица во семејството, мора добро да ги познаваат и мерките и механизмите за заштита од насилство и злоупотреба, како и институциите кои се надлежни да ги преземат, со цел што побрзо и поадекватно да делуваат и да спречат посериозни последици од ваквата состојба. 
Знаења за обезбедување психосоцијална поддршка на старите лица. Социјалната интервенција со стари лица има помагателна функција и во неа се вклучуваат професионалци и од други помагателни професии. Социјалниот работник и психологот имаат клучна улога во давањето на психосоцијална поддршка на старите лица, а во улога на претставник или застапник на социјалните права на старите лица се јавува и правникот.

Според Травитик: „Зборот поддршка е еден од најимпресивните зборови кои се употребуваат во социјалната работа“" (Trevithick, 2009:203). Според Фелтхман и Друден (Feltham and Dryden, 1993): „Тој може да значи скоро сѐ од нудење помош, поддршка, одржување, уверување, водство, охрабрување, валидација, грижа, згрижување и љубов“ (Ibid 1: стр. 203). Оттука може да се разбере и зошто со зборот поддршка, пред сѐ се мисли на емоционалната поддршка, која ја дава една личност кон друга, посебно во период на стрес или криза. Оваа поддршка е посебно значајна од професионалците за старите лица, бидејќи со поддршката старите лица полесно се справуваат со состојбата и продолжуваат понатаму.

Психосоцијалната поддршка има големо значење за секое старо лица кое од најразлични причини се нашло во состојба на социјален ризик и е дел од услугите кои професионалците ги даваат во социјалната интервенција со старите лица. Затоа професионалците вклучени во социјална интервенција со стари лица мора да имаат знаења кои ќе им овозможат адекватна психосоцијална поддршка на старите лица. Од тие причини застапувањето и зајакнувањето се две многу често употребувани техники во социјалната интервенција со стари лица.

Зајакнувањето на старите лица, се прави преку поддршка и нивно поттикнување, односно нивно мотивирање да ја преземат и задржат контролата над сопствениот живот. „Стивенсон и Парслои (Stevenson and Parsloe, 1993) го користат терминот за да ги означат и „процесот и целите“, но според Кларк (Clark, 2000) зајакнувањето многу повеќе се користи за да опише дека на корисниците на услуги им се дава „значајна шанса“ и ,достапни опции“, со цел како што вели Томпсон (Thompson, 2002) да обезбедат поголема контрола над нивниот живот и нивните околности“ (Trevithick, 2009:219). Главен фокус на зајакнувањето е способноста за преговарање со старите лица, според нивните услови и внатрешни капацитети за идентификување на потребите кои ги искажуваат. Професионалците мора да знаат да ги зајакнуваат капацитетите на старите лица, бидејќи без знаења за зајакнување, тие во социјалната интервенција може да започнат да ги наметнуваат сопствените вредности, а притоа да не се ни свесни дека тоа ги обесхрабрува старите лица. Наметнувањето на сопствените вредности од страна на професионалците значи занемарување на нивните лични вредности, што не е во склад со праксата. 
Во зајакнувањето клучен елемент е партиципацијата. Имено, луѓето мора да бидат вклучени во донесувањето на одлуките кои се однесуваат на нивните животи, во процесот преку кој може да стекнат самодоверба, самопочитување и знаења, а наедно да развијат и нови способности. Сепак, партиципацијата сама по себе не е доволна. Освен неа, клучни елементи во моделот се: соработката, учењето и рефлексијата.

„Нузберг (Nuzberg, 1995) индентификува комплексна врска помеѓу факторите кои негативно влијаат на благосостојбата на старите лица, како што се отсуството на ресурси, ниското образование, влошената здравствена состојба и широко раширените ејџистички ставови. Моделот на зајакнувањето во праксата на социјалната работа, ги карактеризира социјалните работници, како некои кои имаат улога на зајакнувачи, кои даваат поддршка и обезбедуваат информации, во контекст на идентификување на потребите на старите лица“" (Lynch, 2016:108).

Во процесот на зајакнување вербалната комуникација бара и високо ниво на свесност на професионалците за време на разговорот со корисниците, и посветување посебно внимание на она што се нуди како готов одговор. Во суштина искусните професионалци избегнуваат нудење готови одговори на корисникот, бидејќи со искуството знаат дека секој корисник е приказна за себе и кон секој треба да се има индивидуален пристап, бидејќи колку и да се наоѓаат корисниците во иста или слична ситуација, не значи дека она што успеало да помогне кај еден корисник, мора да успее и кај другите. Од овие причини професионалците избегнуваат советување и давање предлози и решенија предвреме. Токму затоа професионалците во комуникацијата со корисниците се насочуваат кон употреба на техниката за зајакнување на корисниците, како методски процес и цел на социјалната интервенција, кој овозможува обезбедување високо ниво на психосоцијална поддршка.

Во зајакнувањето не е важно кој на кого ја пренесува моќта, важно е само да се биде свесен и да се разбере нејзиното постоење. Според Томпсон (Thompson, 2001): „Природата на зајакнувањето е во тоа да се поддржат старите лица во зајакнувањето на самите себе" (Lynch, 2016:108). Социјалниот работник кој ги почитува принципите на зајакнување презема три улоги:

- „Пред сѐ ги советува странките како да најдат потенцијална поддршка во семејството, локалната заедница итн. Овде се мисли на активизирање на самата странка;

- Ги учи странките да станат чувствителни на појавата на сопствена беспомошност. Безволноста е резултат на лична неумешност во социјалното или емоционалното функционирање. Според концепцијата на зајакнувањето треба да се развиваат знаења кои се однесуваат на личните недостатоци и да се прават програми за нивно санирање или соодветна комуникација; 
- Третата улога на социјалниот работник е улогата на учител. Се смета дека контролата врз својата средина и околината бара одредено знаење и умешност. Единката или групата која има проблеми со воспоставување правилни односи со својата средина, мора да ги познава причините кои довеле до тоа, мора да ги познава правата и средствата кои овозможуваат да се делува ефикасно“.

(Доневска, 2014:161)

Застапувањето претставува посебно важна техника за секој професионалец. Употребата на застапувањето е толку важно, колку што е важно професионалецот да го пренесе гласот на корисникот чии потреби треба да бидат задоволени во социјалната интервенција. Застапувањето подразбира зборување и дејствување во најдобар интерес на старите лица.

Со застапувањето, во сите негови форми, може да се обезбеди за луѓето, особено за оние кои се најранливи во општеството:

- „да се слушне нивниот глас за прашања што им се важни;

- да ги браниме и заштитиме нивните права;

- н нивните ставови и желби вистински се разгледуваат кога се донесуваат одлуки за нивниот живот“.

(Advocacy, https://www.seap.org.uk/imlooking-for-help-or-support/whatis-advocacy.html)
Со застапувањето, како еден процес на поддршка им се овозможува на луѓето да ги изразуваат пред сѐ сите свои ставови и грижи и им се обезбедува пристап до неопходни информации и услуги. Со застапувањето на старите лица, професионалците едноставно ги бранат и промовираат нивните права и одговорности.

Главен фокус на социјалниот работник е благосостојбата на луѓето, семејствата и заедниците. Затоа клучно за професионалците, пред сѐ за социјалните работници во социјалната интервенција со стари лица е да дејствуваат како застапници. Застапувањето според Томпсон (Thompson, 2002) вклучува: „Претставување на интересите на другите, кога тие не се во можност да го направат тоа за себе си“" (Trevithick, 2009:232). Преку застапувањето професионалците ги штитат ранливите корисници и обезбедуваат услови нивните најдобри интереси да бидат поддржани. Социјалните работници ги застапуваат старите лица во остварување на правата од здравствена и социјална заштита, па сѐ до случаи на остварување на основните човекови права. Застапувањето е посебно важно во случаите на социјална интервенција со стари лица кои имаат когнитивни загуби.

„Застапувањето може да вклучува зборување, пишување, постапување или расправање во име на другите“ (Trevithick, 2009:233). Застапник е оној кој обезбедува поддршка за застапување на корисникот, секогаш кога тоа му е потребно. „Застапникот може да 
ви помогне да добиете информации што ви се потребни или да отиде со вас на состаноци или интервјуа, во поддржувачка улога“ (Advocacy, https:// www.seap.org.uk/im-looking-for-help-orsupport/what-is-advocacy.html).

Професионалците кои ги застапуваат старите лица, може да вршат најразлични задачи во улога на застапувачи од пишување писма, барања и слично, до ситуации да зборуваат за и во име на корисникот, доколку корисникот не може тоа сам да го направи.

Од друга страна социјалните работници ги застапуваат старите лица и нивните семејства на тимските состаноци, и се вовлекуваат на микрониво, но неретки се и случаите кога тие ги застапуваат старите лица пред нивните семејства, бидејќи често пати нивните семејства, односно членовите на нивните семејства имаат различно размислување за тоа што е најдобро за нивните сакани. Во такви ситуации вештините за застапување на професионалците се многу битни, бидејќи можеби не е толку важно што нивните семејства сакаат, туку што е тоа што сакаат и им е потребно на старите лица. Во овие случаи кога професионалците гледаат дека старите лица имаат проблем со личните потреби и желбите на нивните семејства, застапувањето на интересите на старите лица е важна алатка на професионалците.

,Застапувањето има за цел да обезбеди гласовите и интересите на корисниците на услугите да се слушаат и да се одговорат на начини кои ќе влијаат на ставовите, политиката, практиката и испораката на услугите“" (Ibid 1: стр. 233).

Социјалните работници во одредени случаи се должни дури и со закон да ги застапуваат старите лица во остварување на нивните права, посебно во случаи на злоупотреба на постари лица, при известување за какви било сомневања од страна на соодветните органи.

Професионалците кои работат во социјална интервенција со стари лица, како и многу невладини организации и здруженија, често пати се во улога на посредници помеѓу маргинализираните групи и носителите на одлуки. Со користење на техниката на застапување тие им даваат глас на своите членови и на целните групи.

\section{2. РЕЗУЛТАТИ ОД ИСТРАЖУВАЊЕТО}

Истражувањето на знаењата на професионалците за социјална и здравствена заштита на старите лица е комплексна област, па поради тоа истражувањето е реализирано со професионалците и со старите лица. Целта на ваквиот пристап е од една страна да се види потребата на старите лица за социјална и здравствена поддршка, а од друга страна да се видат знаењата со кои располагаат професионалците за социјална и здравствена заштита на старите лица, за да им ја пружат соодветната поддршка на старите лица. Преку ваквиот пристап треба да се направи проценка на потребата за зајакнување на знаењата со 
кои треба да се збогатат програмите за континуирана едукација на професионалците вклучени во социјална интервенција со стари лица. Истражувањето е реализирано во втората половина на месец март и првата половина на месец април 2019 година.

\section{1. ИСТРАЖУВАЮЕ \\ НА ЗНАЕЊАТА НА \\ ПРОФЕСИОНАЛЦИТЕ ЗА \\ СОЦИЈАЛНА И ЗДРАВСТВЕНА \\ ЗАШТИТА НА СТАРИТЕ ЛИЦА}

Со анкетниот прашалник наменет за професионалците опфатени се 61 професионалец, од кои 35 професионалци се вработени во установите за вонсемејна заштита на стари лица, односно сите професионалци од установите за вонсемејна заштита на стари лица, кои во моментот на истражувањето имаа лиценца (дозвола за работа) од Министерството за труд и социјална политика. Од останатите професионалци 21 се вработени во центрите за социјална работа: Меѓуопштински центар за социјална работа Скопје, Меѓуопштин- ски центар за социјална работа Охрид, Меѓуопштински центар за социјална работа Битола, Меѓуопштински центар за социјална работа Дебар, Меѓуопштински центар за социјална работа Берово, Меѓуопштински центар за социјална работа Куманово и Центар за социјална работа Ресен. Од организациите (здруженијата) кои даваат услуги во домот и услуги во заедницата со истражувањето опфатени се 5 професионалци и тоа од: Здружението за поддршка и развој „Хуманост“, Црвен крст на Град Скопје, Црвен крст на Општина Сарај, Црвен крст на Општина Чаир и Црвен крст на Општина Гази Баба. Учеството на професионалците во истражувањето, според видот на установата во која работат графички е прикажано на графикон број 1.

Според податоците, професионалците вработени во установите за вонсемејна социјална заштита на стари лица (установи за социјална заштита на стари лица) изнесуваат $57,4 \%$ од истражувачкиот примерок, а даваат ус-

$$
\begin{aligned}
& \text { Графикон број 1. Испитаници (професионалци) според видот на установата во која } \\
& \text { работат } \\
& \square \text { установа за социјална } \\
& \text { 口центар за социјална } \\
& \text { работа } \\
& \square_{\text {страи јица }}^{\mathrm{HBO} \text { коа дава услуги за }}
\end{aligned}
$$

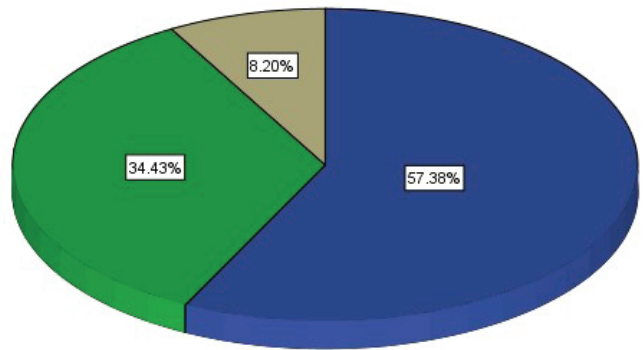


луги кои опфаќаат сместување и 24-часовна нега и грижа за старите лица, $34,4 \%$ се професионалци кои работат во центрите за социјална работа, но на подрачјето на социјална заштита на стари лица и остварување на права и услуги за старите лица во ризик и $8,2 \%$ се професионалци кои работат во здруженија и организации кои даваат услуги во домот и услуги во заедницата (НВО која дава услуги за стари лица). Од значење е да се напомене дека во моментот на истражување, сѐ уште не постои законска обврска за лиценцирање на давателите на услуги во домот и заедницата, а со тоа и професионалците вработени во здруженијата и организациите кои даваат услуги во домот и заедницата не се опфатени со процесот на лиценцирање на стручните работници и нивен континуиран професионален развој.

Според податоците во графикон број 2 , најголем дел од професионалците односно 69\% или 42 стручни работници по професија се социјални работници, што е и клучна професија во социјалната интервенција со стари лица, бидејќи социјалните работници се тие кои се носители на социјалните услуги и работат со корисниците од фазата на прием, преку проценката и планирањето, до самиот чин на давање на услугата, како и поврзување со нивните семејства и сите неопходни чинители, односно ресурси во средината, за да услугата биде согласно потребите на корисниците, односно во случајот согласно потребите на старите лица. Од податоците се гледа дека со истражувањето се опфатени и други професионалци кои имаат значајна улога во социјалната интервенција со стари лица и тоа $11,5 \%$ се психолози, со ист процент од $11,5 \%$ опфатени се правници, со 6,6\% медицински сестри и 1,6\% лекари. Ниската застапеност на медицинските сестри и лекарите, како професионалци со високо образование е одраз на нивната минимална вклученост во социјалните услуги за старите лица, што го остава отворено за размислување прашањето за нивно поинтензивно

Графикон број 2. Испитаници (професионалци) според стручен профил
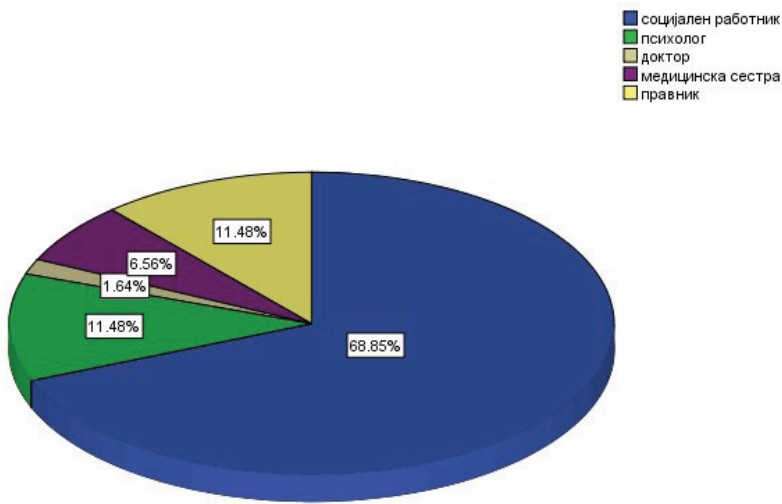
вклучување посебно во домовите за помош и нега и услугите во домот.

Знаењата на професионалците за професионално извршување на работните задачи во обезбедувањето на социјални услуги за старите лица, се важна појдовна точка за нивно професионално ангажирање во оваа област на социјалната работа. За потребите и главната цел на ова истражување од професионалците беше побарано да се изјаснат дали во текот на високото образование имале предмети со кои се стекнале со знаења за социјална интервенција со стари лица. Резултатите од одговорот на ова прашање, се прикажани во табела број 1, од каде може да се види дека од вкупно 61 професионалец, само $42,6 \%$ имале предмети со кои се стекнале со одредени знаења за социјална интервенција со стари лица, а 57,4\% немале предмети од оваа природа. Овие повеќе старите лица имаат потреба од обезбедување социјални услуги.

Социјалната работа, како помагателна професија на лицата кои се наоѓаат во социјален ризик, нуди бројни услуги. Со тоа таа ги опфаќа сите категории на корисници и сите возрасни групи, меѓу кои и старите лица. Затоа во образованието на професионалците кои подоцна се очекува да се вклучат во социјална интервенција и со старите лица, како корисници на услугите, мора да се планираат предмети, со кои професионалците ќе се стекнат со основни геронтолошки и геријатриски знаења и во рамки на кои ќе посетуваат пракса во која ќе развијат основни вештини, за да бидат подготвени за работа со стари лица.

Потребата за знаења и вештини за работа со старите лица произлегува не само од специфичноста на категорија-

Табела број 1. Предмети за стекнување знаења за работа со стари лица

\begin{tabular}{|l|l|l|l|l|}
\hline & $\begin{array}{l}\text { Процент на } \\
\text { фреквенција }\end{array}$ & & $\begin{array}{l}\text { Валиден } \\
\text { процент }\end{array}$ & $\begin{array}{l}\text { Кумулативен } \\
\text { процент }\end{array}$ \\
\hline $\mathrm{He}$ & 35 & 57,4 & 57,4 & 57,4 \\
\hline Да & 26 & 42,6 & 42,6 & 100,0 \\
\hline Вкупно & 61 & 100,0 & 100,0 & \\
\hline
\end{tabular}

податоци ја наметнуваат потребата од подлабоко проучување на прашањето за начините со кои би можела да се зголеми подготвеноста на професионалците за обезбедување социјални услуги за старите лица, имајќи предвид дека населението како во светот, така и во Република Северна Македонија сѐ повеќе старее, а од друга страна поради промените во семејните структури, сѐ та на корисници, односно од специфичностите на староста како фаза од животниот циклус и стареењето како процес, туку и од бројните промени во социјалното опкружување, кои ги носи староста. Од друга страна во современиот начин на живот, сѐ повеќе се менуваат и старите лица и нивните потреби, па се менуваат и пристапите и услугите кои професионалците треба 
да ги користат во работата со старите лица. Имајќи предвид дека 2020 година, посебно ќе остане запаметена по пандемијата со КОВИД-19, во овој дел посебно внимание се посветува на знаењата на професионалците потребни за социјална и здравствена заштита на старите лица.

За нивото на знаења на професионалците, поврзани со ресурсите и услугите за социјална и здравствена заштита, кои многу често се поврзани помеѓу себе и се даваат заедно, бидејќи со староста настапува и опаѓање на виталноста на организмот, според податоците во графикон број 3,41\% од професионалците сметаат дека имаат недоволни знаења, односно сметаат дека не ги познаваат формите и облиците на социјална и здравствена заштита и ресурсите кои ги даваат услугите од социјална и здравствена заштита. Други $27,9 \%$ од професионалците сметааат дека имаат основни знаења од оваа група, но и нивните знаења треба да се зајакнат. Останатите $31 \%$ од професионалците сметаат дека имаат доволни знаења од оваа група. Ова значи дека само 31\% од професионалците немаат потреба од дополнителни знаења во оваа област, додека останатите $69 \%$ имаат потреба од зајакнување на знаењата и тоа дури $41 \%$ имаат високо ниво на потреба од зајакнување на знаењата во оваа група, бидејќки имаат недоволни знаења. Причина за ваквата состојба со оваа група на знаења може да бидат и недоволно развиените ресурси за поддршка на локално ниво, но тоа не може да биде оправдување за непознавање на ресурсите кои постојат, како и видот на услугите кои тие ги даваат и воспоставувањето на соработка со нив.

Покрај нивото на знаења на професионалците за социјална и здравствена заштита на старите лица, преку статистика на фреквенции (видот на знаења со бодирање), направен е преглед на ви-

Графикон број 3. Ниво на знаења на професионалците за социјалната и здравствената заштита на старите лица

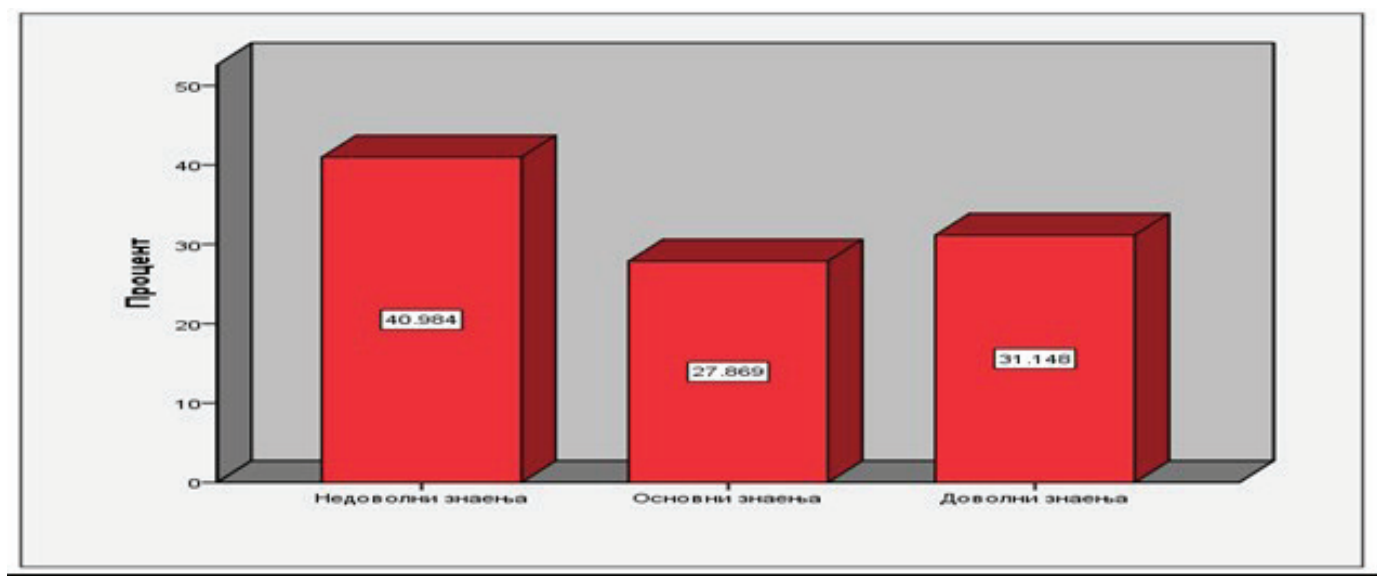


довите на знаења во самата група, при што може да се заклучи дека знаењата за: мапирање на здравствени сервиси и услуги, мапирање на социјални сервиси и услуги, услови за користење услуги, психосоцијална поддршка на старите лица, права и услуги од социјална заштита и заштита од семејно насилство и злоупотреба се движат во фреквенција од 150 до 200, од максимум 250, при што професионалците се изјасниле дека имаат најмалку знаења за заштита на старите лица од семејно насилство и злоупотреба, а најмногу за мапирање на здравствени сервиси и услуги.

\section{2. ИСТРАЖУВАҢЕ НА ПОТРЕБИТЕ НА СТАРИТЕ ЛИЦА ЗА СОЦИЈАЛНА И ЗДРАВСТВЕНА ПОДДРШКА}

За да се утврди нивото на потреба од поддршка на старите лица вклучени во социјална интервенција и поврзаноста на поддршката и потребата од зајакнување на знаењата на професионалците, со истражувањето е опфатен и примерок од стари лица кои добиваат социјални услуги во установи за вонсемејна заштита, како и стари лица корисници на услуги во домот или на услуги во заедницата.

Со анкетниот прашалник наменет за старите лица опфатени се 70 стари лица, од кои 54 стари лица се корисници на услугите во јавни и приватни установи за вонсемејна социјална заштита на стари лица: ПУС3 „Руски“ - Кадино, ЈОУ Дом за стари лица „Киро Крстевски-Платник“ - Прилеп, ЈОУ
Дом за стари лица „Зафир Сајто“ - Куманово, и 16 стари лица корисници на услуги во домот и услуги во заедницата на Црвен крст на Град Скопје, Црвен крст на Општина Чаир, Црвен крст на Општина Сарај и Црвен крст на Општина Гази Баба и Здружението за поддршка и развој ,Хуманост“.

Опфатеноста на старите лица со ова истражување е прикажана на графикон број 4. Податоците покажуваат дека со истражувањето се опфатени 70 стари лица, од кои 77,1\% се корисници на услуги од институционална или вонсемејна заштита и 22,9\% се корисници на услуги од вонинституционална заштита или услуги во домот и услуги во заедницата. Овој сооднос на стари лица вклучени во истражувањето согласно видот на услугите кои ги користат е резултат на поголемата развиеност на услугите за вонсемејна заштита во однос на услугите во домот и услугите во заедницата, во Република Северна Македонија.

Во Република Северна Македонија старите лица имаат многу повеќе можности да користат услуги од вонсемејна заштита, за разлика од услугите во домот и заедницата, бидејќи ресурсите за овие даватели на услуги сѐ уште не се развиени, но реформите во системот на социјална заштита и воведувањето на лиценцирани и овластени даватели на социјални услуги се очекува да придонесат кон развој на услугите во домот и услугите во заедницата.

Дека старите лица во Република Северна Македонија имаат незадоволе- 
на потреба од поддршка со социјални услуги, покажуваат и резултатите од некои претходни истражувања на подрачјето на нашата земја, па истите се употребени за компарација со резултатите добиени во ова истражување, во насока на согледување на потребата за подигање на квалитетот и квантитетот на социјалните услуги за старите лица.

За потребите на ова истражување во прашалникот за проценка на потребите за поддршка на старите лица, направени се групи на прашања кои треба да ја проценат потребата од здравствена здравствената поддршка им е потребна, но на $35,7 \%$ истата им е многу неопходна. Ова значи дека повеќе од три четвртини од старите лица имаат потреба од одредено ниво на здравствена поддршка, додека само 22,9\% од старите лица немаат потреба од здравствена поддршка. Дека старите лица имаат потреба од здравствена поддршка се потврдува и во истражувањето од 2017 година, но: „Оддалеченоста на здравствената институција е најчеста причина за непосетување лекар за старите лица од Полошкиот $(24,2 \%)$ и од Североисточ-

Графикон број 4. Испитаници (стари лица) според видот на услугите кои ги користат

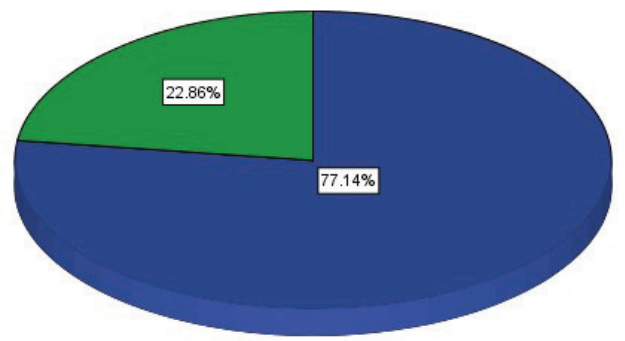

поддршка на старите лица и потребата од социјална поддршка.

По направената обработка и групирање на податоците за проценка на потребата од здравствена поддршка (прашања од 5 до 11) се доаѓа до резултатите прикажани во графикон број 5 , кои укажуваат дека дури 77,1\% од старите лица имаат потреба од здравствена поддршка, но на различно ниво, односно дека на 41,4\% од старите лица ниот Регион (19,2\%)“. (Димитријоска, С., Станојковска, Д., 2017:40). Резултатите од двете истражувања покажуваат дека старите лица имаат потреба од здравствена поддршка, но се поставува прашањето: Дали сите ја добиваат и во кој обем?

За определување на нивото на потреба од здравствена поддршка значаен е и одговорот на прашањето: Кој се грижи за старото лице за време на бо- 
лест? Од прашалникот за проценка на потребите на старите лица вклучени во социјална интервенција, прикажан во табела број 2., од каде според фреквенциите се гледа дека во над $18 \%$ од случаите најмногу за време на болест за нив се грижи брачниот другар, во 17\% од случаите за нив се грижат нивните соседи, во околу $13 \%$ од случаите нивните деца и со ист процент (13) се изјасниле за нивните роднини. Ова се резултати кои зборуваат за неформалната поддршка која ја добиваат старите лица за време на болест од најблиските во средината во која живеат, додека околу $27 \%$ се изјасниле дека кога се болни за нив за време на болест се грижи стручен тим и тоа во $14,3 \%$ од институционална заштита, што значи дека овие лица се сместени во установи за вонсемејна заштита и за нив се грижи тимот кој работи во оваа установа. Во
$12,9 \%$ од старите лица во ова истражување се изјасниле дека за нив во случај на болест се грижи стручен тим од вонинституционална заштита, што значи дека овие лица се корисници на услуги во домот или услуги во заедницата. Во $8,6 \%$ од случаите се плаќа човек кој се грижи за нив за време на болест. Одговорите на ова прашање зависат и од последните искуства кои ги имале старите лица вклучени во социјална интервенција за време на болест, односно кој ја преземал грижата за нив додека биле болни.

Слични на резултатите од ова истражување се и резултатите од истражувањето од 2017 година, кои покажуваат дека: „На прашањето кој најчесто се грижи за старото лице додека е болно, најголем број 39,8\% одговориле - брачниот другар, потоа децата со кои живее $33,7 \%$, и децата што доаѓаат да му по-

Графикон број 5 . Ниво на потреба од здравствена поддршка на старите лица

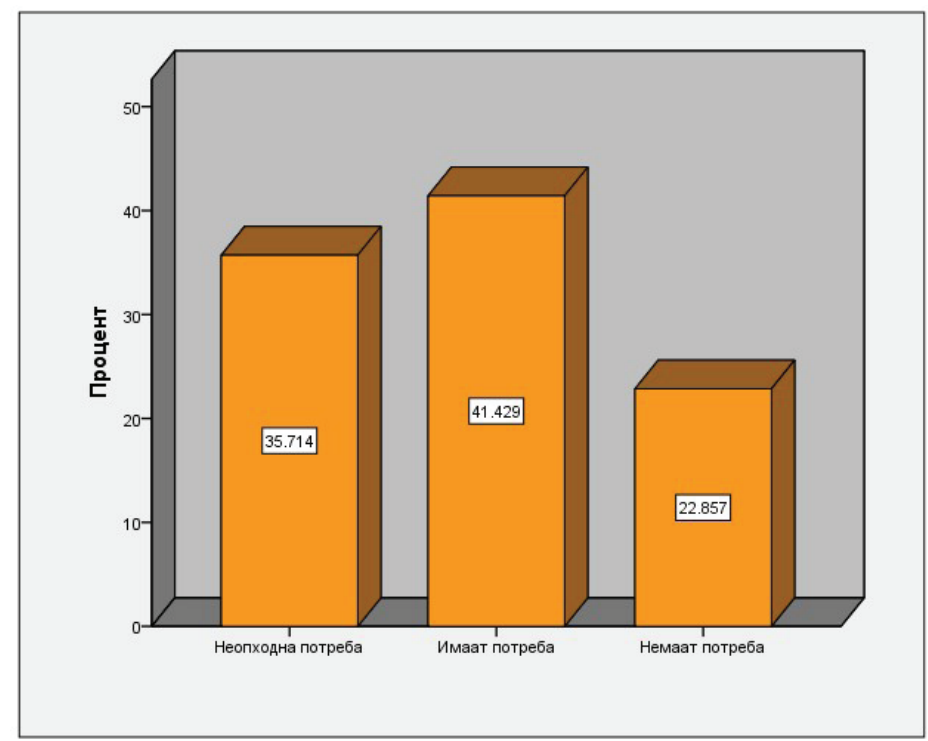


Табела број 2. Грижа за старите лица за време на болест

\begin{tabular}{|c|c|c|c|c|}
\hline & & $\begin{array}{r}\text { Процент на } \\
\text { фреквенција }\end{array}$ & $\begin{array}{r}\text { Валиден } \\
\text { процент }\end{array}$ & $\begin{array}{r}\text { Кумулативен } \\
\text { процент }\end{array}$ \\
\hline Брачен другар & 13 & 18,6 & 18,6 & 18,6 \\
\hline Деца & 9 & 12,9 & 12,9 & 31,4 \\
\hline Роднини & 9 & 12,9 & 12,9 & 44,3 \\
\hline Соседи & 12 & 17,1 & 17,1 & 61,4 \\
\hline Пријатели & 2 & 2,9 & 2,9 & 64,3 \\
\hline Плаќа човек & 6 & 8,6 & 8,6 & 72,9 \\
\hline $\begin{array}{l}\text { Стручен тим од институционална } \\
\text { заштита }\end{array}$ & 10 & 14,3 & 14,3 & 87,1 \\
\hline $\begin{array}{l}\text { Стручен тим од вонинституционална } \\
\text { заштита }\end{array}$ & 9 & 12,9 & 12,9 & 100,0 \\
\hline Вкупно & 70 & 100,0 & 100,0 & \\
\hline
\end{tabular}

могнат $12,9 \%$ од испитаниците“" (Димитријоска, С., Станојковска, Д., 2017:35).

При влошена здравствена состојба, старите лица не само што имаат потреба од грижа и нега онаму каде што живеат, туку имаат и потреба од дополнителни консултативни прегледи со определен вид на лекари - специјалисти, чие мислење е клучно за здравствената нега и грижа која треба да ја добива старото лице, преку стручен тим од медицински сестри и негувателки. Затоа во истражувањето опфатени се и видот на потребите на старите лица од здравствена поддршка од лекар и видот на потребите од здравствена поддршка од медицинска сестра. Од истражувањето од 2017 година: ,За здравствената заштита од лекар и од медицинска сестра, дури $17 \%$ од старите лица се изјасниле дека им е многу потребна, a $16,2 \%$ дека им е умерено потребна“ (Ibid 1: стр:75).
Во графиконот број 6, прикажани се фреквенциите за потребата од здравствена поддршка од лекар, односно од каков вид на лекар или специјалист најмногу им е потребна здравствена поддршка на старите лица. Од овие податоци се гледа дека на старите лица, најмногу (20\%) им се потребни прегледи од кардиолог, општ лекар 15,7\%, интернист 14,3\%. Интересен е и податокот дека на $11,43 \%$ од старите лица опфатени со ова истражување, а кои се вклучени во социјална интервенција неопходно им е сместување во здравствена установа. Ова зборува и за неопходноста за поширок мултидисциплинарен пристап во социјалната интервенција, кој се препознава преку неопходноста од вклучување лекари со различни специјализации. Оваа потреба е во согласност и со реформите на системот на социјална заштита кој овозможува склучување договори по- 
меѓу социјални и здравствени установи, а и развивање установи за вонсемејна заштита, како домови за помош и нега.

Графиконот број 7, ги прикажува фреквенциите за видот на потребата од здравствена поддршка од медицинска сестра. Од него се гледа дека во $37,14 \%$ услугата од медицинска сестра е потребна поради давање и контрола на таблетарна терапија, во 30\% поради давање ампуларна и интравенозна терапија и во $32,9 \%$ поради контрола на здравствената состојба, што зборува за високо ниво на потреба од поддршка од медицинска сестра. Медицинската сестра е онаа која е задолжена за рутинските медицински прегледи, притисок, крв, терапија (таблетарна, мускулна, интравенозна), но и која најдобро ги воочува промените кај старите лица поради честиот директен контакт со нив. И резултатите од истражувањето од 2017 година покажуваат дека: „Во однос на услугите што ги добиваат од патронажната служба, најголем број на стари лица изјавиле дека тоа е мерењето крвен притисок, 51,8\%, а 11\% од старите лица одговориле дека тоа е мерење шеќер, дел од нив добиле инфузија и проверка на маснотии“ (Димитријоска, С., Станојковска, Д., 2017:42), додека во однос на потребната помош во правилно и навремено земање лекови: „На

Графикон број 6. Потреба од здравствена поддршка на старите лица од лекар

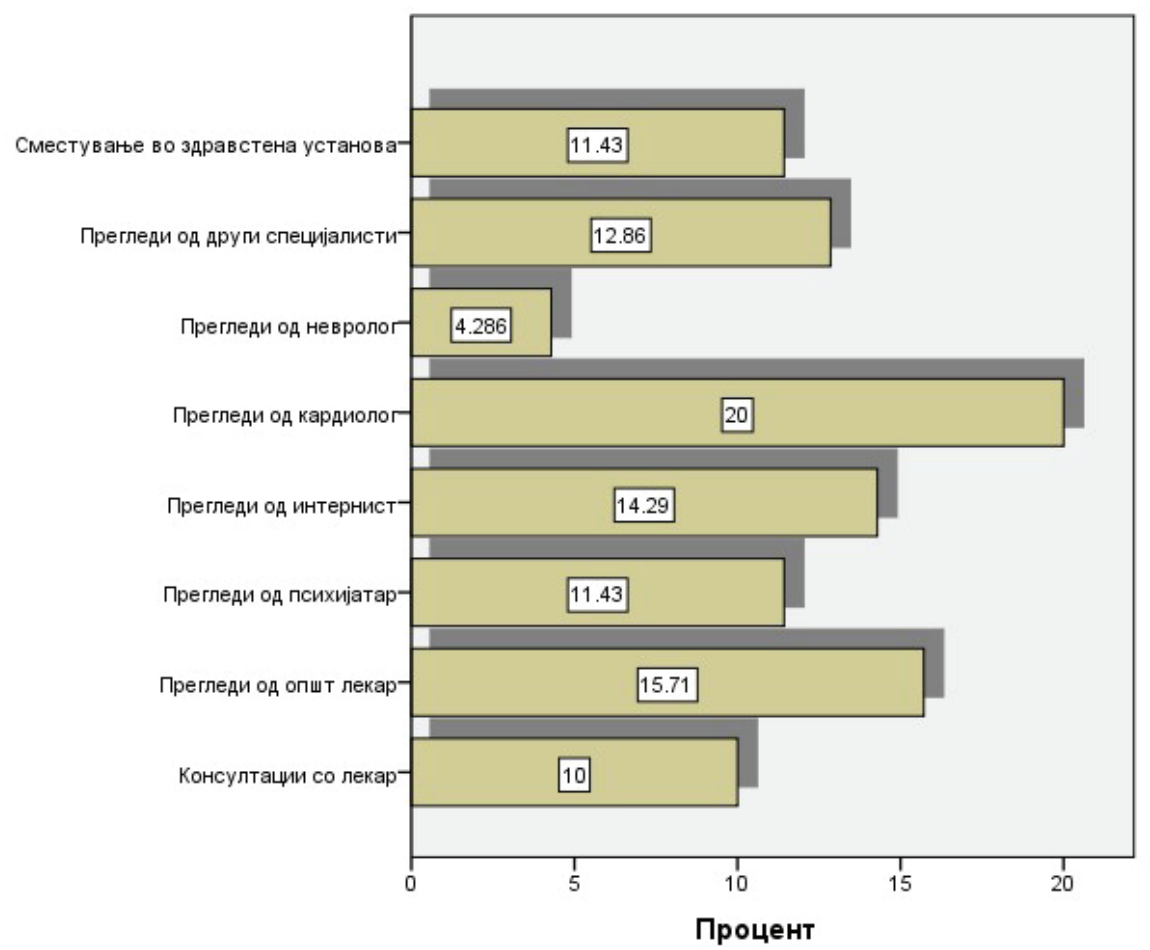


Графикон број 7. Вид на потреба од здравствена поддршка на старите лица од медицинска сестра

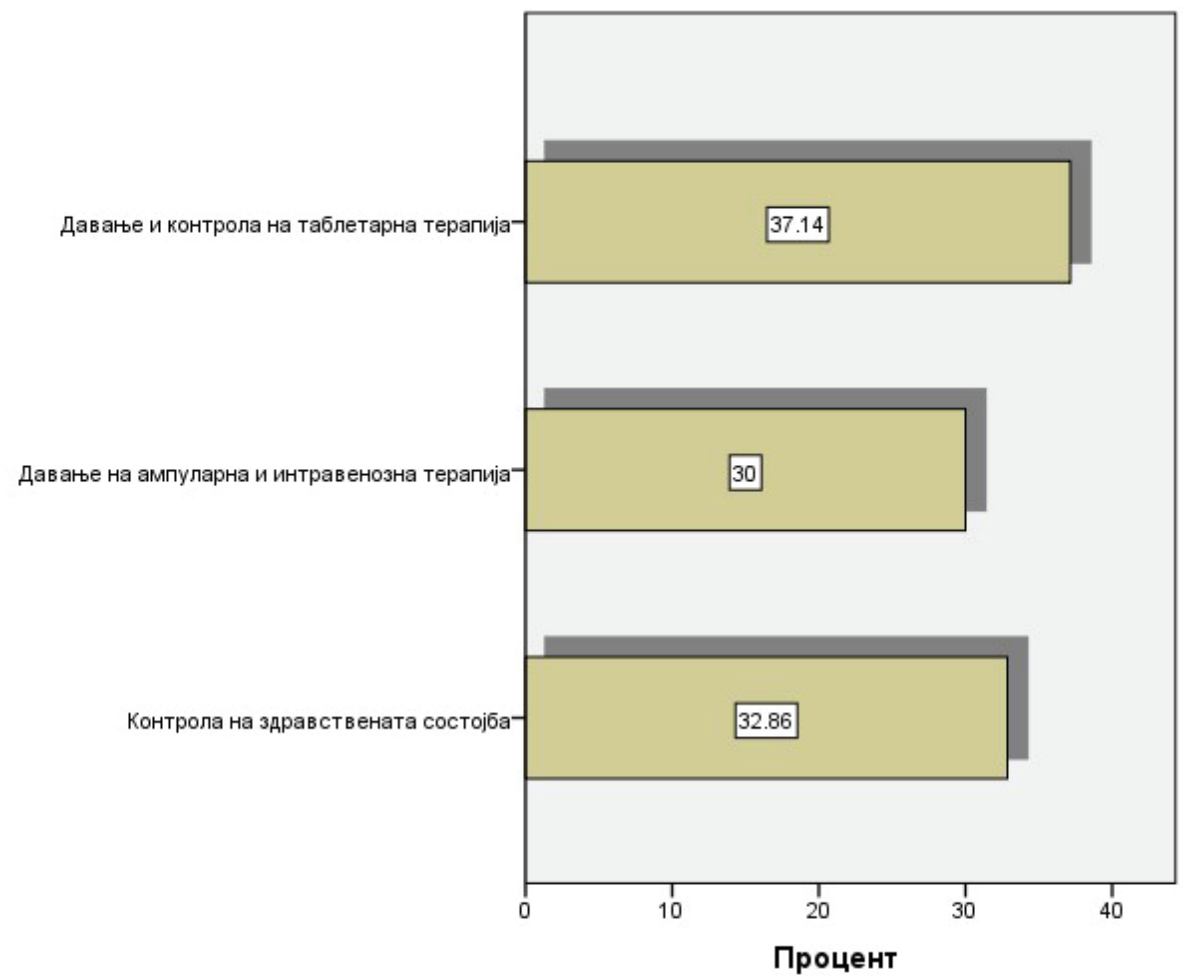

$12,2 \%$ им е многу потребна, а на 9,2\% им е умерено потребна“" (Ibid 1: стр. 75).

Социјалната поддршка се однесува на сите оние активности или работни задачи кои ги има социјалниот работник во спроведувањето на социјалната интервенција со старото лице. По обработката и класификацијата на податоците од групата на прашања поврзани со проценка на потребата од социјална поддршка на старите лица кои се вклучени во социјална интервенција, се добија резултатите кои се прикажани во графикон број 8.

Од податоците во графикон број 8, се гледа дека социјалната поддршка им е потребна на 78, 7\% од старите лица вклучени во социјална интервенција и тоа на две нивоа: на околу 43\% социјална поддршка им е потребна, а на други $35,7 \%$ им е потребна во обем на неопходност. Само 21,4\% од испитаниците (стари лица) се изјасниле дека немаат потреба од социјална поддршка. Ова зборува дека повеќе од три четвртини од старите лица имаат потреба и од социјална поддршка.

Суштината на активностите кои ги реализира социјалниот работник во социјалната интервенција со старите лица е од една страна да им овозможи остварување на одредени права и услуги од 
социјална заштита, но и да помогне во одржување на социјалните контакти и социјалната активност на старите лица, со што ќе ја подигне нивната самодоверба и ќе помогне во одржување на нивното физичко и ментално здравје. Социјалниот работник сето ова може да го постигне преку реализација на вежби за физичка активност, психосоцијална поддршка, советувања на одредени теми од социјалното функционирање, едукации, активности за културен и забавен живот, придружба на старото лице за остварување на одредени потреби во социјалната средина, обезбедување исхрана или дневно згрижување, обезбедување одредена поддршка од некои здруженија и организации кои даваат услуги од социјална заштита и слично.

Податоците прикажани во графикон број 9, покажуваат дека на старите лица од социјалните работници најнеопходна им е поддршката со која ќе се обезбеди нивно работно и волонтерско ангажирање $(15,7 \%)$, потоа поддршка на членовите на нивните семејства (14,29\%), и со $11,43 \%$ поддршка во остварување на права од социјална заштита и советувања и едукации на одредени теми од секојдневниот живот.

Во социјалната интервенција со старите лица важна улога имаат и негувателите и/или геронтодомаќинките, кои во зависност од обликот на социјалната заштита играат важна улога во извршување на секојдневните активности за и со старото лице. Тие се оние кои најдиректно работат во задоволување на основните животни потреби, од одржување лична хигиена на старото лице, хигиена на леглото и облеката, набавка на намирници, подготовка на храна, уплата на сметки, придружба на одредени настани и слично. Според податоците во графикон број 10, на старите лица

Графикон број 8. Ниво на потреба од социјална поддршка на старите лица

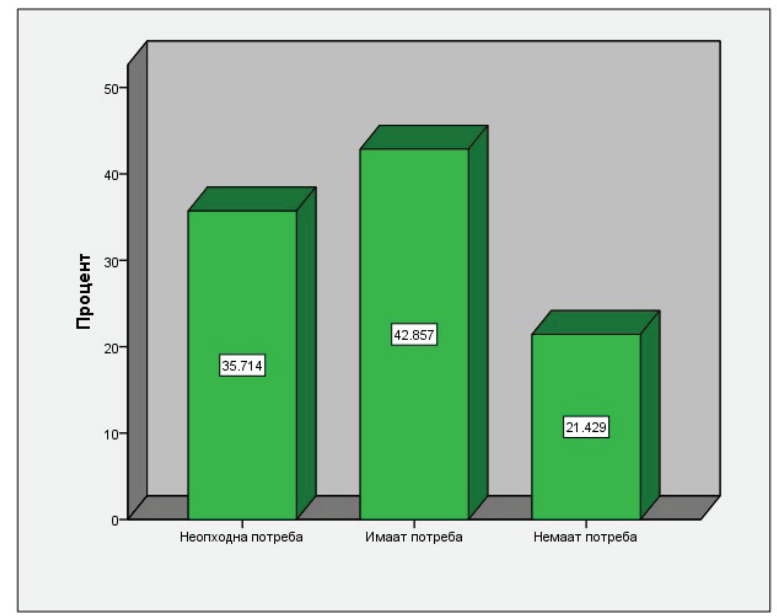


Графокон број 9. Вид на потребна поддршка на старите лица од социјален работник

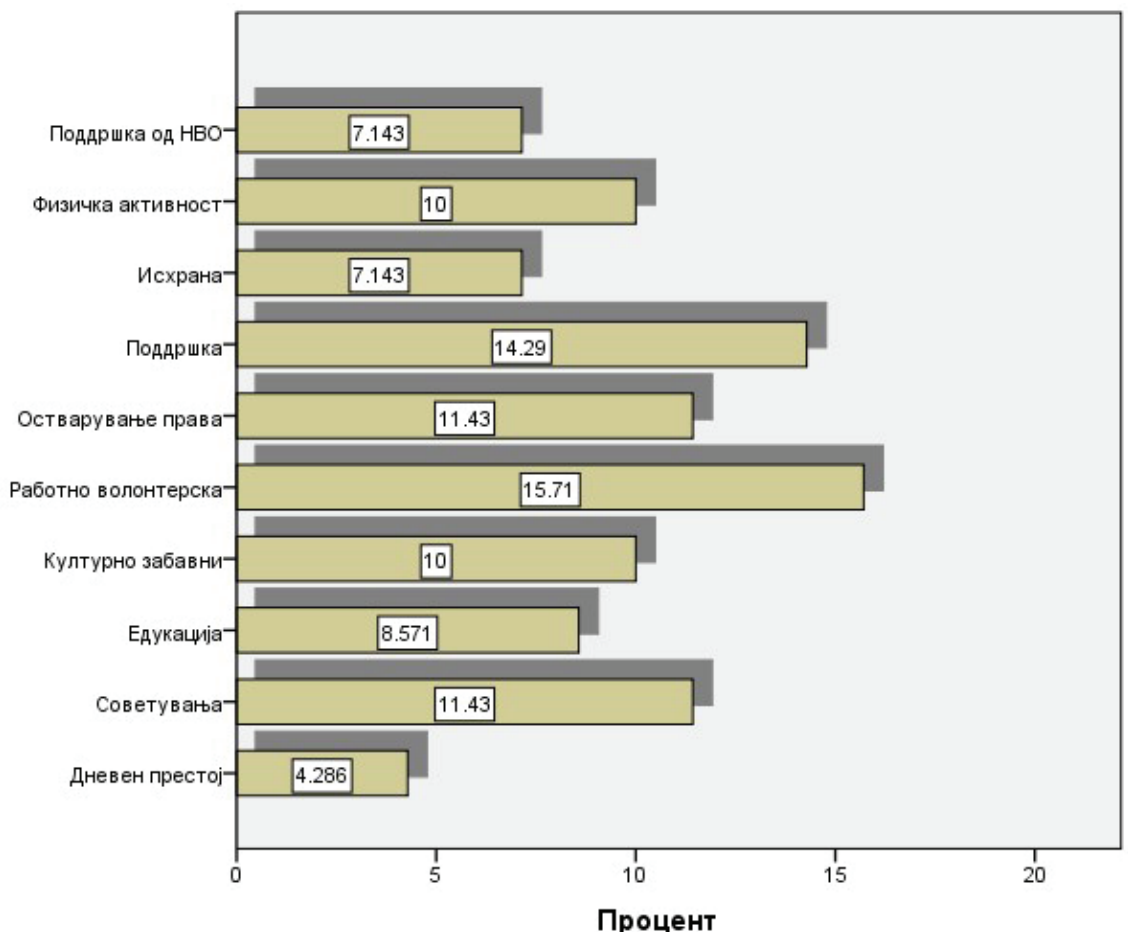

од негувателите/геронтодомаќинките, најмногу им е неопходна поддршка за уплата на сметки 18,57\% и придружба $17,14 \%$. На 12,86\% неопходна им е помош во набавка на намирници, а на $10 \%$ помош во облекување и соблекување и исто толку проценти (10\%) се изјасниле за потребата за одржување, односно помош во одржување на личната хигиена. Неопходноста од овие социјални услуги за старите лица се потврдува и во истражувањето од 2017 година и тоа: „,15,9\% од старите лица опфатени со истражувањето се изјасниле дека услугата набавка на намирници им е многу потребна и 11,9\% дека им е умерено потребна; 12,7\% сметаат дека услугата подготвување храна им е многу потребна, а 11,9\% дека им е умерено потребна; помош во исхраната им е многу потребна на 9,4\%, а умерено потребна на 7,2\% од испитаниците; на 6\% од старите лица многу им е потребна помош во облекување/соблекување, а умерено потребна на 8,8\% од старите лица; за одржување на личната хигиена, 9,8\% од старите лица се изјасниле дека им е многу потребна помош, а 10,7\% дека им е умерено потребна помош; на $11,1 \%$ од старите лица им е многу потребна помош за одржување хигиена на леглото и на исто толку стари лица оваа помош им е умерено потребна; на 12,6\% им е потребна помош во 
одржување хигиена на облеката, а на $11,2 \%$ умерено им е потребна помош во одржување хигиена на облеката; придружувањето при посета на специјалистички лекар, болници и слично им е потребна на $35,6 \%$ од старите лица, додека на 17,6\% помошта за оваа услуга им е многу потребна, а на $15,1 \%$ им е умерено потребна“" (Димитријоска, С., Станојковска, Д., 2017:73-76).

\section{3. СОЦИЈАЛНИТЕ УСЛУГИ \\ ЗА СТАРИ ЛИЦА ВО \\ РЕПУБЛИКА СЕВЕРНА \\ МАКЕДОНИЈА ЗА ВРЕМЕ НА \\ КОВИД-19}

Состојбата со пандемијата КОВИД-19 предизвика промени и ограничувања на услугите од социјална и здравствена заштита наменети за стари лица. Преку деск анализа на информации добиени од самите установи за вонсемејна заштита на стари лица, може да се констатира дека установите не беа подготвени за справување со пандемијата, но исправени пред предизвици-

Графикон број 10. Вид на потребна поддршка на старите лица од негувател/ геронтодомаќинка

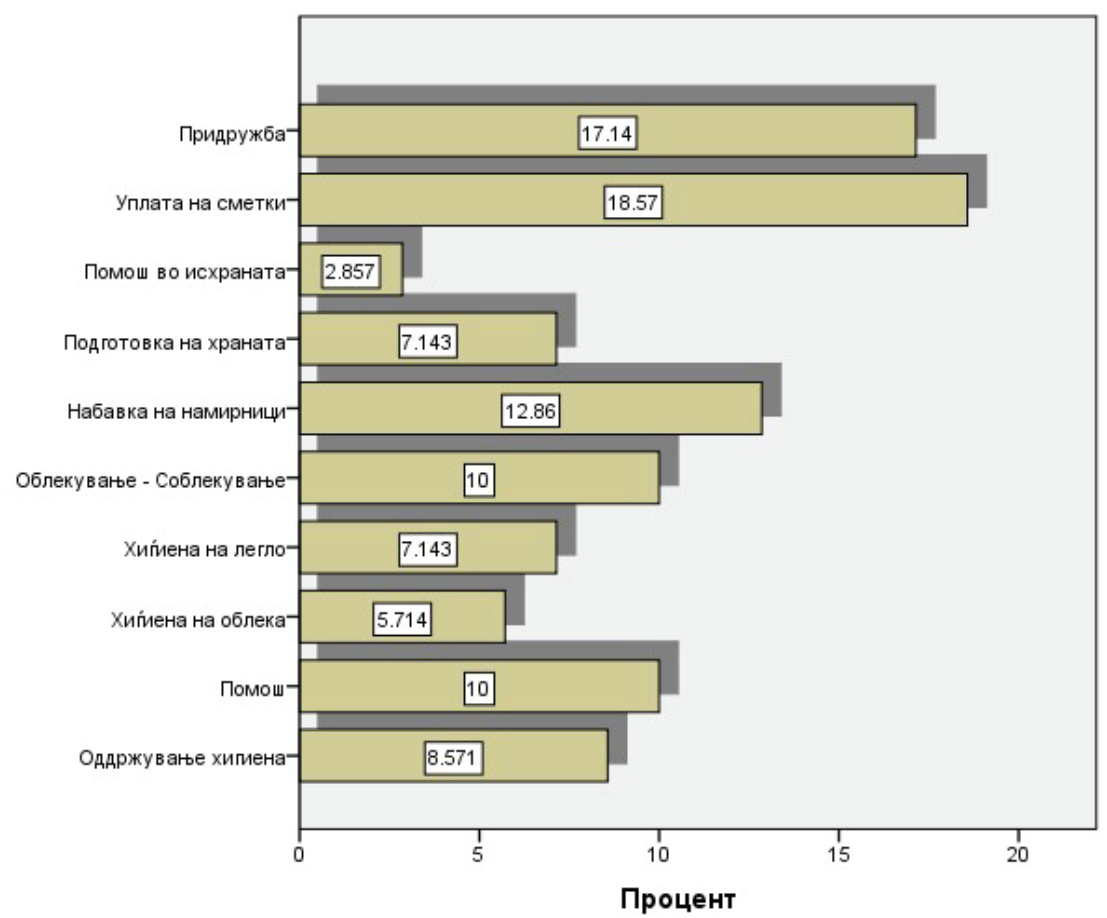


те чекор по чекор се соочуваа и приспособуваа кон новонастанатата состојба.

Воведувањето на вонредната состојба и ограничувањето на движењето, првобитно претставуваше најголем проблем, поради неможноста на вработените во установите да стигнат на своето работно место. Установите за да овозможат навремени и континуирани услуги за старите лица, организираа превоз за вработените до работното место. Вработените се организираа во тимови, работат 7/10//14 дена во установата, без да заминат дома и без замена во наведениот рок.

Друг предизвик претставуваше набавката на маски, заштитни ракавици, заштитни одела, опрема и средства за дезинфекција, посебно на почетокот на пандемијата кога овие ресурси беа ограничени. Пристапот до набавка на медицински помагала и лекарства на почетокот беше ограничен, поради ограниченото работно време на установите. Во установите каде што имаше можности корисниците преку работно и волонтерско ангажирање самостојно изработуваа маски за потребите на установата. Сите установи постапуваа согласно препораките на Министерството за здравство.

Во однос на корисниците најголем предизвик за нив претставуваше воведувањето на забрана за посети, со што контактите во живо со членовите на семејствата беа заменети со видео или телефонски контакти. Во однос на услугите во самите установи истите продолжија да се даваат 24 часа како и претходно, но со зголемени мерки на заштита и со промена на методолошкиот пристап, односно групната социјална работа и социјалните контакти помеѓу корисниците беа сведени исклучиво на индивидуална работа на вработените со корисниците.

Друг предизвик кој претставуваше и еден вид ограничување на социјалните услуги во установите за вонсемејна заштита за нови корисници, е забраната за прием на нови корисници, која ја воведоа речиси сите установи за вонсемејна заштита на стари лица и која во одредени установи траеше сѐ до донесување на протоколите кои се изготвуваа во соработка со центрите за јавно здравје. Установите кои постепено ја олабавуваат забраната за прием на нови корисници, задолжително при прием на нови корисници бараат ПСРтест, не постар од 72 часа и новите корисници се сместуваат во посебни соби за изолација, со карантински мерки во траење од 14 дена.

Со оглед на тоа што старите лица повеќе се подложни на инфекции и вируси многу често сезонскиот грип или други заболувања на корисниците во установите за социјална заштита на стари лица налагаа состојби на изолација и транспорт до установи за здравствена заштита, што беше ограничено само на итни потреби од здравствена заштита.

Старите лица кои живеат во своите сопствени домови, имаа многу малку ресурси во заедницата, кои им овозможуваа обезбедување социјални услуги 
за време на КОВИД-19. Црвен крст на Град Скопје и Здружението за поддршка и развој беа меѓу ретките организации кои им набавуваа храна и намирници, лекови и други средства неопходни за живот на старите лица и ги дистрибуираа до нивните домови. Многу стари лица на целата територија на Република Северна Македонија мораа индивидуално да се снаоѓаат во однос на набавката на намирници во услови на ограничено движење и КОВИД-19.

Во однос на здравствената заштита, сите термини за прегледи во системот „Мој термин“ беа откажани, а болниците беа подготвувани да одговорат на предизвиците на КОВИД-19. Со тоа многу тековни, хронични состојби кај старите лица не претставуваа приоритет во услови на КОВИД-19, а здравствените служби беа достапни само во услови на итност.

\section{ЗАКЛУЧОК СО ПРЕПОРАКИ}

Истражувањето на знаењата на професионалците за социјалната и здравствената заштита на старите лица, покажуваат потреба од зајакнување на овие знаења кај професионалците и тоа дури кај 69\%. Од нив 41\% имаат високо ниво на потреба од зајакнување на знаењата во оваа група, бидејќи имаат недоволни знаења.

Од друга страна истражувањето покажа дека старите лица имаат зголемена потреба од социјална и здравствена поддршка, односно 77,1\% од старите лица имаат потреба од здравствена поддршка, (на 41,4\% здравствената поддршка им е потребна, а на $35,7 \%$ истата им е многу неопходна) и $78,7 \%$ од старите лица имаат потреба од социјална поддршка (на 43\% социјална поддршка им е потребна, а на други $35,7 \%$ им е потребна во обем на неопходност).

Појавата на пандемија со КОВИД-19, укажа на слабоста на системот во Република Северна Македонија, поточно на неповрзаноста на социјалните и здравствени услуги за старите лица. Непостоењето на протоколи за постапување во услови на пандемии и кризни ситуации, отсуството на мрежна поврзаност на социјалните и здравствените ресурси во заедницата, непознавањето на институциите и услугите кои тие ги даваат, како и недоволната развиеност на услугите во домот и заедницата влијаеја на квалитетот и квантитетот на социјалните и здравствените услуги.

Овие три состојби неминовно ја наметнуваат потребата од зајакнување на знаењата на професионалците за социјална и здравствена заштита на старите лица, вклучувајќи ги тука и знаењата за постапување во услови на криза и епидемии. Збогатување на содржината на програмите за континуиран професионален развој со содржини од оваа тематика е еден од начините за зајакнување на знаењата на професионалците. 


\section{КОРИСТЕНА ЛИТЕРАТУРА}

Advocacy, (No date) [Online], Avalible from: https://www.seap.org.uk/im-looking-for-helpor-support/what-is-advocacy.html) [Acceseed May, 2019].

Димитријоска, С., Станојковска, Д., (2017) Анализа од спроведено истражување на тема: Потреба од социјални и од здравствени сервиси за старите лица, Црвен крст на Република Македонија, Здружение за унапредување на условите за грижа и сместување стари и изнемоштени лица „Хуманост“.

Доневска, М., (2006), Социјалната работа во локалната заедница, Филозофски факултет - Скопје.

Доневска, М., (2014) Теоретските основи на социјалната работа, Филозофски факултет - Скопје.

Gilmore, R. L., (2013) Motivations, Skills and Rewards: Social Workerжs Perspectives on Practise with Older Adults, Master of Social Work Clinical Research Papers, Minnesota (No date) [Online], Avalible from: https://sophia.stkate.edu/cgi/viewcontent. cgi?article $=1181 \&$ context $=$ msw_papers [Acceseed 5 May, 2016].

Lynch, (Linc), R., (2016) Praksa socijalnog rada sa starima: Pozitivan pristup centriran ka osobi, Fakultet politickih nauka, Univerzitet u Beogradu.

Oxford Dictionary of English (2010) Oxford University Press, Third Edition.

Trevithick, P., (2009), Social Work Skills: A practice handbook, second edotion, Open University Press. 